\title{
Article \\ The Effect of ESG Activities on Financial Performance during the COVID-19 Pandemic-Evidence from Korea
}

\author{
Juhee Hwang, Hyuna Kim * and Dongjin Jung
}

check for updates

Citation: Hwang, J.; Kim, H.; Jung, D. The Effect of ESG Activities on Financial Performance during the COVID-19 Pandemic-Evidence from Korea. Sustainability 2021, 13, 11362. https://doi.org/10.3390/su132011362

Academic Editor: Michael R.

Langemeier

Received: 7 September 2021

Accepted: 12 October 2021

Published: 14 October 2021

Publisher's Note: MDPI stays neutral with regard to jurisdictional claims in published maps and institutional affiliations.

Copyright: (c) 2021 by the authors. Licensee MDPI, Basel, Switzerland. This article is an open access article distributed under the terms and conditions of the Creative Commons Attribution (CC BY) license (https:// creativecommons.org/licenses/by/ $4.0 /)$.
School of Business Administration, Kyungpook National University, 80, Daehak-ro, Buk-gu, Daegu 41566, Korea; jhhwang10@knu.ac.kr (J.H.); jdj1875@knu.ac.kr (D.J.)

* Correspondence: hyunakim@knu.ac.kr

\begin{abstract}
This study examines the effect of a firm's environmental, social, and governance (ESG) activities on its financial performance during the acute uncertainty caused by the COVID-19 pandemic. Due to the COVID-19 pandemic, most Korean firms suffered unexpected difficulties in their business activities in early 2020, and their financial performance deteriorated significantly. The purpose of this study is to empirically analyze whether a firm's ESG activities affect its financial performance during a business crisis. The results show that, in the first quarter of 2020, when the impact of the COVID-19 pandemic occurred, firms' earnings dropped significantly; however, we found that the higher the performance of ESG activities, the smaller the decline in earnings. The results imply that, in an environment of uncertainty, the performance of a firm's ESG activities is reflected in its financial outcomes. This result implies that trust and bond between firms and stakeholders, as formed through investments in social capital, are rewarded when the overall level of sustainability in markets is negatively impacted. In addition, our results suggest that the performance of nonfinancial activities is useful information for stakeholders' decision making in relation to market uncertainty.
\end{abstract}

Keywords: COVID-19; ESG; financial performance; social capital

\section{Introduction}

As the COVID-19 pandemic affected capital market volatility in the first quarter of 2020, the financial condition of most firms in South Korea deteriorated significantly. This unpredictable environment continues as the COVID-19 pandemic persists. South Korea's gross domestic product recorded a negative growth rate $(-1.0 \%)$ in 2020 , and the KOSPI index declined to 1400 in the first quarter of 2020. Roubini (2020) [1] predicts that the COVID-19 pandemic will have a greater impact than the Great Depression, as it is not an economic crisis but a health crisis. Therefore, a different approach is required to handle the current business crisis caused by the COVID-19 pandemic. For example, the spread of nonface-to-face transactions in the future will significantly change the business environment that existed before COVID-19, thus changing the management paradigm of multiple firms. Therefore, companies' new business strategies must be accompanied by ways in which to overcome unexpected crises.

In recent times, companies are paying more attention to and exerting more effort in environmental, social, and governance (ESG) management. ESG management is not a new management method; it is an operation method based on a strategy for shared growth with stakeholders. As typical capitalism of the past, which is only interested in maximizing shareholders' wealth, has had negative effects on societies (e.g., social and environmental problems), there has been a lot of discussion about corporate social responsibility (CSR) and corporate sustainability management, which apply to all corporate activities, spanning to the more recent form of ESG management. This study aims to explore how ESG management is related to corporate financial performance and how it can be a way to overcome the business crisis caused by the COVID-19 pandemic. 
In previous studies, there are various viewpoints and mixed research results on the relationship between ESG activities and corporate financial performance. According to a negative understanding of ESG, activities increase cost, making it economically disadvantageous [2]. This is because ESG activities reduce available resources, making it difficult for firms to respond to an unexpected business crisis. If ESG activities are driven by opportunistic motives (e.g., to enhance the reputation of managers), expenditures related to ESG activities will only become costs rather than investments and will undermine the value of a firm [3]. In this respect, some studies argue that ESG activities negative effect financial performance, or there are not related [4,5].

Conversely, ESG activities positively influence a firm's financial outcomes in both a direct and an indirect way, thereby enhancing its competitive advantage and shareholder value, such as improving operating efficiency [6], employee productivity [7], and capital market benefits [8,9]. From a positive ESG perspective, this is because socially and environmentally responsible business activities help create long-lasting benefits by increasing trust - a form of social capital — in a company and building bonds with stakeholders [10].

As such, previous studies examine the direct and indirect effects of ESG activities on firm value from various perspectives. In order to directly observe the effects of a firm's ESG activities, an environment with exogenous variation at the firm level is appropriate. Otherwise, it is difficult to attribute changes in financial outcomes to the performance of ESG activity. An exogenous unexpected shock is out of the balance, while ESG levels remain largely unchanged in the short term. According to Lins et al., (2017) [10], they limited the analysis period to the financial crisis period (2008-2009) in order to more clearly understand the effect of ESG activity performance on firm value. As a result of the analysis, during the financial crisis, firms with high CSR activity performance showed higher financial performance, including ROA.

Unlike Lins et al., (2017) [10], this study analyzes the role of ESG during the COVID-19 pandemic. The current economic shock is different from the financial crisis in that it was caused by factors outside the economy per se. In other words, at the time of the financial crisis, the reliability of corporate information was important due to concerns about information asymmetry. However, during the COVID-19 pandemic, efficient allocation of resources is of utmost importance due to there being limited resources and damage to the value of resources caused by national lockdowns. Therefore, under the environment of increased uncertainty due to COVID-19, the financial outcome of a firm will be differentiated according to the effect of social capital created by said firm's ESG activities.

This study investigates how the performance of a company's ESG activities affects its financial performance under the business crisis caused by the COVID-19 pandemic. Most companies in South Korea reported that their profitability deteriorated in the first quarter of 2020 because of the COVID-19 pandemic, so we examine whether ESG activities affected their financial performance. Therefore, we analyze the empirical results from before (i.e., the first quarters of 2018 and 2019) and during the COVID-19 pandemic (i.e., the first quarter of 2020), using 1645 firm-quarter data about Korean listed firms.

We chose the Korean stock market to examine this hypothesis for several reasons. First, ESG scores are available for almost all stocks listed in the Korea stock market. Second, Chaebols, that is, large conglomerates that are family-owned businesses, account for a large proportion of Korean listed firms, and their decision-making influences on the market are sizeable. As a result, social problems caused by corporate arbitrariness are serious, and the demand for transparent governance and socially responsible activities is higher than in any other country.

The results show that financial performance, measured by return on assets (ROA), fell sharply in the first quarter of 2020 because of the COVID-19 pandemic, but the extent of the decline is smaller for companies with higher performance in ESG activities, especially in two subdimensions of ESG-social responsibility (S) and governance (G). These results imply that companies that invested in ESG activities to coexist with their stakeholders and promote fair and transparent corporate management benefited by achieving stable 
management performance during the business crisis. Furthermore, although, on average, firms' earnings volatility increased in the first quarter of 2020, we found that the higher the ESG performance, the lower the earnings volatility.

This study provides the following contributions. Recently, studies on the impact of the COVID-19 pandemic on capital markets and firm value have been actively conducted [11,12]. Most studies deal with declines in financial performance and firm value, but this study differs in that it focuses on factors that mitigate the impact of uncertainty on firms. Additionally, this study is important because it empirically examines the effect of ESG activities on corporate financial performance during the COVID-19 pandemic. Whereas existing research showed mixed findings on the relationship between ESG activities and corporate financial performance, this study shows that ESG activities have a positive effect on financial performance during the business crisis caused by the COVID-19 pandemic. This study supports the argument that ESG activities play an important role in increasing a firm's value under market uncertainty.

The structure of this paper is as follows. Following the introduction, Section 2 reviews the related prior research and establishes the research hypothesis. Sections 3 and 4 describe the research methods and sample selection, and Section 5 presents the results of the data analysis. Finally, Section 6 summarizes the results and presents the conclusions.

\section{Background and Hypothesis}

\subsection{ESG Activities}

In recent times, many companies have been paying attention to forms of sustainable management that consider environmental and social responsibilities, as well as economic performance, as sustainable growth cannot be achieved by focusing only on economic performance. CSR is well known as decisions and behaviors that are compatible with socially desirable goals and values [13]. Social issues and ethical responsibilities arising from relationships with various stakeholders are the main frameworks of CSR. Moreover, compared with CSR, ESG is a concept that includes a wider range of nonfinancial factors; it comprises three subdimensions-environmental responsibility (E), social responsibility $(S)$, and governance $(G)$ - each of which entail various nonfinancial activities. Whereas CSR is relatively focused on the social aspect, ESG emphasizes balancing the three factors without skewing to one factor. In modern management, interest in the environmental factor is growing faster than the social factor, and the standards for transparent corporate governance are higher, especially in South Korea. Therefore, from the perspective of corporate sustainability management, which dominates modern corporate management philosophy, ESG, which encompasses a wider range of social values, is emphasized more than CSR.

The pursuit of CSR or ESG activities for corporate sustainability management can be explained using stakeholder and legitimacy theories. The stakeholder theory explains that shareholders are not the only group with a stake in a firm, and there are other stakeholders, including investors, creditors, employees, and consumers, as well as society and the environment [14]. Therefore, a firm's interest in society and the environment is desirable due to the interests of all stakeholders of the firm, and the pursuit of these interests should be consistent with the firm's goal of sustainable management. The legitimacy theory, which is a new institutional perspective, explains that investment in these activities may be costly in the short term, but the legitimacy of a firm increases and receives a positive evaluation from stakeholders in the long term [15]. This means that it is necessary to secure legitimacy from stakeholders' perspectives to obtain various resources and necessary support for the survival and performance of a firm [16].

However, some view a firm's ESG activities as inefficient and unhelpful in increasing the firm's value, or as activities driven by a manager's opportunistic personal motive. From this point of view, ESG activities consume and reduce a firm's limited resources that should be used to improve shareholders' wealth, which in turn increases costs and decreases profits, thereby weakening the firm's status. Prior et al., (2008) [17] argue that CSR activities 
are carried out to hide negative corporate activities (e.g., earnings management) and avoid stakeholder scrutiny. Similarly, the agency theory proposes that managers will use ESG activities as a tool to enhance their personal reputation, and there is a possibility of using shareholder's equity to implement ESG activities [18].

\subsection{ESG Activities and Corporate Performance}

Just as conflicting theories exist to explain ESG activities, there are also differences in interpreting the effects of ESG activities. In particular, there are no consistent conclusions about the impact of ESG activities on a firm's value and financial performance.

First, a number of studies document a positive association between ESG activities and firm performance, suggesting "doing good by doing well" $[5,19,20]$. Luo and Bhattacharya (2006) [21] show that CSR activities satisfy stakeholders, which leads to higher corporate performance in the long run. Using data from 559 samples in 28 countries, Surroca et al., (2010) [22] found a positive relationship between CSR and financial performance through the formation of intangible assets. These results indicate that, when a firm engages in socially responsible activities, intangible assets, and these intangible assets contribute to financial performance. Aboud and Diab (2018) [23] also find that the socially and environmentally responsible activities of a firm with good corporate governance satisfy the interests of stakeholders, which can improve financial performance. Lins et al., (2017) [10] explore the relationship between CSR as a proxy for social capital and firm performance during the 2008-2009 financial crisis. They find that firms that have built stakeholder trust and cooperation through social capital can obtain excess returns during the financial crisis in which public trust in commercial transactions has declined unexpectedly. On the other hand, Edmans (2011) [24] suggest that high-CSR firms outperform low-CSR firms even in the non-crisis periods. Li et al., (2019) [25] examine stock market reactions to corporate social performance. They find that socially responsible firms generate positive abnormal returns, but only for a short period. Specifically, they show that firms with better social performance are more likely to have positive earnings, and they also show that investors react more strongly when firms with a high CSR performance show a comparable financial performance. These findings support the fact that investors perceive socially responsible performance positively. This study demonstrates that firms with high ESG performance maintain stable financial outcomes based on good relationships with stakeholders, including investors. Additionally, Kang and Jung (2020) [26] analyze whether the effect of ESG activities on firm value depends on corporate financial characteristics using data provided by the Korea Corporate Governance Service and WHO'S GOOD. They find that the effect of ESG activities is more pronounced in firms with high profitability and foreign ownership ratios, implying that the effects of ESG activities can be different depending on corporate financial characteristics. These results indicate that a firm's ESG activities have a positive effect on said firm's performance, but this effect moderated by the firm's characteristics.

Moreover, some studies report that ESG activities have a negative impact on firm value by making firms incur additional costs. These studies focus on the perspective of shareholders and argue that ESG activities have a negative effect on financial performance because it is difficult to obtain direct benefits beyond expenses. Hillman and Keim (2001) [27] find that investing in the relationship with major stakeholders is a valuable activity that can secure competitiveness from a corporate standpoint, but ESG activities that invest in the environment and society do not lead to corporate value creation. Brammer et al., (2006) [28] examine the relationship between ESG activities and financial performance in UK firms, and find that firms with high ESG scores tend to achieve relatively lower returns, and that corporate social activities undermine shareholder value. Duque-Grisales and Aguilera-Caracuel (2021) [29] also confirm the negative relationship between ESG scores and corporate performance in Latin American countries. Byun (2018) [30] examines the effect of ESG ratings on corporate value using the data of ESG ratings released by the Korea Corporate Governance Service from 2011 to 2014. She finds that ESG activities do not have 
a positive effect on corporate value and that environmental activities specifically reduce corporate value. Meanwhile, Yeo et al., (2015) [31] argue that the impact of CSR activities on a firm's future financial performance differs depending on the degree of industry competition. They find that, the higher the level of competition in the industry in which a firm belongs, the more aggressively it carries out CSR activities, suggesting that CSR activities have a positive effect on improving financial performance. However, they also find that there is no significant correlation between CSR activities and financial performance among firms in low-competitive industries. Thus, a firm's ESG activities can have a different effect on financial performance depending on the characteristics of the industry or market in which the firm belongs.

\subsection{Hypothesis Development}

The COVID-19 pandemic, which began at the end of 2019, is having an unprecedented impact on the entire global economy [32]. The COVID-19 pandemic has created an economic crisis in $92.9 \%$ of countries worldwide, which is considerably larger than the $4.9 \%$ during the smallpox pandemic of the 1870 s and the $83.3 \%$ during the Great Depression of the 20th century [33]. The business crisis caused by the COVID-19 pandemic is different from crises that have hit the capital market in the past. In addition to the recent strategies of firms turning to ESG management, the business crisis caused by the COVID-19 pandemic is creating a sizeable change in corporate management strategies. As shown in previous studies, a firm's ESG activities can affect its financial performance during the business crisis caused by the COVID-19 pandemic in the following three ways.

First, if a firm's ESG activities are part of said firm's social capital and have a positive effect on building trust with its stakeholders, a friendly relationship with stakeholders is maintained even during the current uncertain situation caused by the COVID-19 pandemic [34]. Like trust, social capital can reduce transaction costs and inefficiency by lowering information asymmetry between a firm's insiders and outside investors and enhance organizational performance by strengthening the unity of internal and external resources [35,36]. Additionally, from a firm's perspective, the cost of building social capital through ESG activities is more profitable when business crises occur unexpectedly. Therefore, investment in social capital, such as ESG activities, can be thought of as a kind of insurance policy that allows firms to receive compensation when faced with severe business crises. Additionally, stakeholder and investor commitment help firms deemed to be more trustworthy during the crisis [10]. Therefore, we expect that the higher the ESG management performance, the lower the degree of financial performance deterioration during the first quarter of 2020, when most firms' financial performance deteriorated.

However, although ESG activities can have a direct or indirect positive effect on longterm corporate value, they can lead to costs and become burdensome in the short term $[4,5]$. A firm's active ESG investment can become a factor that makes efficient management difficult by preventing firms from securing resources necessary to survive during a business crisis, during which the real economy suddenly deteriorates. Therefore, it is expected that, in times of uncertainty, the higher a firm's ESG management performance, the worse its short-term financial performance.

Meanwhile, the performance of these ESG activities may not be reflected as financial performance. It is possible that ESG ratings do not measure firms' investment in ESG activities and the performance of those activities well. In particular, the sample of this study is Korean listed firms, and the history of Korean firms' active ESG activities is relatively short. Moreover, the evaluation results are somewhat different depending on the institutions that evaluate ESG activities. Thus, if social capital has not yet been formed to the extent that the performance of ESG activities is visible, or if the ESG rating itself is an inappropriate measure, the relationship between a firm's ESG management performance and its financial performance during the business crisis caused by the COVID-19 pandemic may not be found. Therefore, this study proposes the following null hypothesis. 
Hypothesis 1 (H1). The relationship between ESG activities and financial performance does not differ during the business crisis caused by the COVID-19 pandemic.

\section{Methodology}

\subsection{Measuring ESG Performance}

In many previous studies, ESG data from external organizations that evaluate a firm's ESG activity are used as a measure of ESG activity performance. Although it is possible to know the performance of ESG activities through voluntary or mandatory disclosure information by a firm, subjective factors by management cannot be completely excluded from the information directly disclosed. Therefore, in this study, ESG activity performance was also measured based on the evaluation data of reliable external agencies. This ESG rating is a measure of how much a company has built up social trust and bonds with its stakeholders through ESG activities [10,37].

We use the CSR ratings provided by the Korea Corporate Governance Service (KCGS) ESG database to measure firms' CSR performance. KCGS's ESG ratings are widely used in research about the Korean capital market.

The number of institutions that evaluate and report ESG activities for Korean firms is increasing, and the evaluation results of each institution are different. Early empirical studies on ESG in Korea predominantly used the KEJI index provided by the Citizens' Coalition for Economic Justice, but the KEJI index is limited because it only provides evaluation data for the top 200 listed firms. Moreover, the KCGS has been evaluating the level of corporate governance of most KOSPI-listed firms and some KOSDAQ firms since 2003. However, in recent times, the scope of evaluation has been expanded, and KCGS has reported the ESG rating that evaluates the overall ESG activities of firms. Since KCGS's ESG ratings target relatively more firms than the KEJI index, the frequency of ESG-related studies using KCGS's ESG ratings in Korea has increased [38].

KCGS does not disclose the evaluation score in detail and reports the ESG integrated grade and grades for individual categories (i.e., environmental responsibility, social responsibility, and governance) using seven grades ( $, A+, A, B+, B, C$, and D). In this study, we use a continuous variable (ESG_SCORE) that takes on 3 for an A+ grade or higher, 2 for an A grade, 1 for a $B+$ grade, and 0 for a grade $B$ or lower as the main empirical proxy for ESG performance. In addition, we use an indicator variable (ESG_FIRM) measured as 1 for a $\mathrm{B}+$ grade or higher and 0 for below $B$ grades.

\subsection{Empirical Model}

To examine the relationship between ESG and financial performances during the business crisis caused by the COVID-19 pandemic, we estimate Equation (1) as follows:

$$
\begin{aligned}
& R O A_{i, t}=\alpha_{0}+\alpha_{1} E S G_{i, t_{-} 1}+\alpha_{2} \operatorname{COVID}_{t}+\alpha_{3} E_{S G_{i, t_{-} 1}} \times \operatorname{COVID}_{t}+\alpha_{4} S I Z E_{i, t_{1} 1}+\alpha_{5} L E V_{i, t_{-} 1} \\
& +\alpha_{6} R O A_{i, t_{-} 1}+\alpha_{7} G R W_{i, t_{-} 1}+\alpha_{8} M B_{i, t_{-} 1}+\alpha_{9} \text { Foreign }_{i, t_{-} 1}+\alpha_{10} O W N_{i, t_{-} 1} \\
& +\alpha_{11} A G E_{i, t}+\alpha_{12} C A S H R_{i, t_{-} 1}+\alpha_{13} L_{O S S} S_{i, t}+\sum I N D+\varepsilon_{i, t},
\end{aligned}
$$

where the variables for year $t$ and firm $i$ are defined as follows:

$$
\begin{aligned}
& R O A_{i, t}=\begin{array}{l}
\text { Financial performance is measured as net income divided by the } \\
\text { opening total assets; }
\end{array} \\
& E S G_{i, t} \quad=\quad \text { ESG ratings (as previously defined) at the beginning of the year; } \\
& \text { COVID }_{t}=\text { During the COVID-19 pandemic in 2020; } \\
& \text { Firm size (SIZE), leverage ( } L E V) \text {, firm performance }(R O A) \text {, sales } \\
& \text { Control growth rate }(G R W) \text {, market-to-book ratio }(M B) \text {, foreign investors } \\
& \text { variables }=\text { rate (Foreign), share of largest shareholders }(O W N) \text {, firm age }(A G E) \text {, } \\
& \text { cash holdings (CASHR), and loss firm (LOSS) (see Appendix A for }
\end{aligned}
$$

We use Equation (1) to examine whether there is a significant relationship between ESG, an independent variable representing the performance of a firm's ESG activities in the previous period, and ROA, a dependent variable representing the firm's financial perfor- 
mance. ROA is the source of excess returns, so we use it as a proxy for the firm's financial performance [10]. By using the coefficient of the interaction between ESG and COVID, we examine whether ESG performance has an incremental impact on financial performance during the business crisis caused by the COVID-19 pandemic. If ESG performance is more (less) likely to enhance a firm's financial performance during the business crisis caused by the COVID-19 pandemic than usual, the coefficient of ESG $\times \operatorname{COVID}\left(\alpha_{3}\right)$ in Equation (1) is predicted to be positive (negative). To control for other firm characteristics that may affect current profitability, we include control variables in the model. We include firm size $(S I Z E)$, leverage $(L E V)$, ROA $(R O A)$, sales growth $(G R W)$, market-to-book ratio $(M B)$, foreign ownership rate (Foreign), share of largest shareholder $(O W N)$, firm age $(A G E)$, cash holdings (CASHR), loss firm (LOSS), and industry fixed effects as control variables. We define the variables in Appendix A.

\section{Sample Selection and Descriptive Statistics}

\subsection{Sample Selection}

We manually obtained ESG ratings from reports disclosed by KCGS. Then, we matched the ESG data with financial data from the Total Solution 2000 database provided by the Korea Listed Firms Association. In this study, to analyze the difference in the impact of ESG activities on financial performance during and before the COVID-19 pandemic, we set the COVID-19 pandemic period as Q1 2020 and the period before the COVID-19 pandemic as Q1 2018 and 2019. Therefore, we include KOSPI-listed firms on which ESG rating information from 2017 to 2019 and financial data for the first quarter of 2017 to 2020 are available. We exclude financial institutions and firms whose fiscal year does not end in December because the characteristics of their financial information differ from those of firms in other industries. We classify industries based on two-digit industry classification codes. The final sample included 1645 firm-year observations. All continuous variables were winsorized at the 1st and 99th percentiles to mitigate the potential effect of outliers. The quarterly data used for the analysis are presented in Table 1.

\subsection{Descriptive Statistics}

Panel A of Table 2 reports the descriptive statistics of the variables used in our regressions. The mean value of ESG_SCORE is 0.311 and the value of the third quartile is 0 , which implies that most of the ESG ratings of the sample firms are below the B grade. The mean and median values of $R O A$, measuring financial performance for the first quarter of 2018-2020, are $0.6 \%$, whereas the mean (median) value of $R O A_{t-1}$ is $0.9 \%(0.7 \%)$. This indicates that financial performance has declined.

Panel B of Table 2 compares the descriptive statistics of the variables during and before the COVID-19 pandemic. The mean value of ESG_SCORE during the COVID-19 pandemic is significantly higher than before the COVID-19 pandemic. These results imply that, as stakeholder interest in ESG activities increases, firms are more actively engaged in ESG activities than before.

The mean value of ROA before (during) the COVID-19 pandemic is $0.008(0.004)$, and the mean value of LOSS before (during) the COVID-19 pandemic is 0.245 (0.323). As we mentioned before, these results imply that firms' profitability has deteriorated significantly and the number of firms experiencing financial difficulties due to the COVID-19 pandemic has increased significantly.

Panel C of Table 2 compares the descriptive statistics of the variables of ESG and nonESG firms. We observe that ESG firms are larger (SIZE) and have better earnings performance $(R O A, L O S S)$ than nonESG firms. We also find that ESG firms and are younger (AGE) and have better corporate governance (Foreign, OWN).

Table 3 reports the Pearson correlation matrix of the main variables. We find that a firm's financial performance $(R O A)$ is positively correlated with ESG activity (ESG_SCORE) but significantly and negatively correlated with the COVID-19 pandemic (COVID). The relationship between ESG_SCORE and COVID is statistically insignificant. 
Table 1. Sample selection and distribution.

\begin{tabular}{|c|c|c|}
\hline \multicolumn{3}{|c|}{ Panel A: Sample Selection } \\
\hline \multicolumn{2}{|r|}{ Sample Selection Criteria } & Firm-Year \\
\hline \multicolumn{2}{|c|}{ Firms trading on the Korean Stock Exchange from 2018 to 2020} & 2331 \\
\hline \multicolumn{2}{|c|}{ Delete baking firms and non-December fiscal years } & $(538)$ \\
\hline \multicolumn{2}{|c|}{ Delete firms with missing data for financial measures and ESG scores } & $(148)$ \\
\hline \multicolumn{2}{|r|}{ Final sample } & 1645 \\
\hline \multicolumn{3}{|c|}{ Panel B: Sample distribution by year } \\
\hline year & 2019. 1Q & 2020. 1Q \\
\hline number & 533 & 566 \\
\hline \multicolumn{3}{|c|}{ Panel C: Sample distribution by industry } \\
\hline 2-digit code & Description & $\mathrm{N}$ \\
\hline 10 & Manufacture of food products & 71 \\
\hline 13 & Manufacture of textiles, except apparel & 37 \\
\hline 14 & $\begin{array}{l}\text { Manufacture of wearing apparel, clothing } \\
\text { accessories, and fur articles }\end{array}$ & 49 \\
\hline 17 & $\begin{array}{l}\text { Manufacture of pulp, paper, and paper } \\
\text { products }\end{array}$ & 66 \\
\hline 20 & $\begin{array}{l}\text { Manufacture of chemicals and chemical } \\
\text { products except pharmaceuticals and } \\
\text { medicinal chemicals }\end{array}$ & 187 \\
\hline 21 & $\begin{array}{l}\text { Manufacture of pharmaceuticals, medicinal } \\
\text { chemicals, and botanical products }\end{array}$ & 109 \\
\hline 22 & \multirow{2}{*}{$\begin{array}{l}\text { Manufacture of rubber and plastic products } \\
\text { Manufacture of other nonmetallic mineral } \\
\text { products }\end{array}$} & 62 \\
\hline 23 & & 69 \\
\hline 24 & Manufacture of basic metal products & 125 \\
\hline 25 & $\begin{array}{l}\text { Manufacture of fabricated metal products, } \\
\text { except machinery, and furniture }\end{array}$ & 34 \\
\hline 26 & $\begin{array}{l}\text { Manufacture of electronic components, } \\
\text { computer, radio, television, and } \\
\text { communication equipment and apparatuses }\end{array}$ & 115 \\
\hline 28 & Manufacture of electrical equipment & 55 \\
\hline 29 & $\begin{array}{l}\text { Manufacture of other machinery and } \\
\text { equipment }\end{array}$ & 77 \\
\hline 30 & $\begin{array}{l}\text { Manufacture of motor vehicles, trailers, and } \\
\text { semitrailers }\end{array}$ & 106 \\
\hline 31 & \multirow{2}{*}{$\begin{array}{l}\text { Manufacture of other transport equipment } \\
\text { Electricity, gas, steam, and air conditioning } \\
\text { supply }\end{array}$} & 26 \\
\hline 35 & & 28 \\
\hline 41 & General construction & 86 \\
\hline 46 & $\begin{array}{l}\text { Wholesale trade and commission trade, except } \\
\text { motor vehicles and motorcycles }\end{array}$ & 111 \\
\hline 47 & $\begin{array}{l}\text { Retail trade, except motor vehicles, and } \\
\text { motorcycles }\end{array}$ & 31 \\
\hline 49 & \multirow{2}{*}{$\begin{array}{l}\text { Land transport, transport via pipelines } \\
\text { Professional services }\end{array}$} & 30 \\
\hline 71 & & 171 \\
\hline \multicolumn{2}{|l|}{ Total } & 1645 \\
\hline
\end{tabular}


Table 2. Descriptive statistics.

\begin{tabular}{|c|c|c|c|c|c|c|}
\hline \multicolumn{7}{|c|}{ Panel A: Descriptive Statistics of the Sample } \\
\hline Variable & $\mathbf{N}$ & Mean & Std. dev. & 25th & Median & 75th \\
\hline ESG_SCORE $E_{t-1}$ & 1645 & 0.311 & 0.625 & 0.000 & 0.000 & 0.000 \\
\hline Escore $_{t-1}$ & 1645 & 0.723 & 1.027 & 0.000 & 0.000 & 2.000 \\
\hline Secore $_{t-1}$ & 1645 & 0.894 & 1.135 & 0.000 & 0.000 & 2.000 \\
\hline Gscore $_{t-1}$ & 1645 & 3.028 & 0.951 & 2.000 & 3.000 & 4.000 \\
\hline COVID $_{t}$ & 1645 & 0.344 & 0.475 & 0.000 & 0.000 & 1.000 \\
\hline$R O A_{t}$ & 1645 & 0.006 & 0.019 & -0.001 & 0.006 & 0.014 \\
\hline$S I Z E_{t-1}$ & 1645 & 20.569 & 1.577 & -19.442 & 20.374 & 21.501 \\
\hline$L E V_{t-1}$ & 1645 & 1.580 & 6.829 & 0.499 & 0.965 & 1.616 \\
\hline$R O A_{t-1}$ & 1645 & 0.009 & 0.023 & 0.001 & 0.007 & 0.015 \\
\hline$G R W_{t-1}$ & 1645 & 0.110 & 1.559 & -0.051 & 0.028 & 0.122 \\
\hline$M B_{t-1}$ & 1645 & 1.441 & 5.888 & 0.559 & 0.853 & 1.444 \\
\hline Foreign $_{t-1}$ & 1645 & 0.117 & 0.130 & 0.024 & 0.067 & 0.163 \\
\hline$O W N_{t-1}$ & 1645 & 0.435 & 0.160 & 0.317 & 0.438 & 0.543 \\
\hline$A G E_{t}$ & 1645 & 3.637 & 0.602 & 3.367 & 3.829 & 4.043 \\
\hline $\mathrm{CASHR}_{t-1}$ & 1645 & 0.085 & 0.079 & 0.034 & 0.063 & 0.108 \\
\hline LOSS $_{t}$ & 1645 & 0.272 & 0.445 & 0.000 & 0.000 & 1.000 \\
\hline \multicolumn{7}{|c|}{ Panel B: Difference Tests of Variables (Pre and Post COVID-19 Pandemic) } \\
\hline & \multicolumn{2}{|c|}{$\begin{array}{c}\text { COVID }=0 \\
(n=1079)\end{array}$} & \multicolumn{2}{|c|}{$\begin{array}{c}\text { COVID }=1 \\
(n=566)\end{array}$} & \multirow{2}{*}{$\begin{array}{c}t \text {-Tests } \\
(p \text {-Value })\end{array}$} & \multirow{2}{*}{$\begin{array}{c}\text { Wilcoxon } \\
\text { Tests } \\
\text { ( } p \text {-Value) }\end{array}$} \\
\hline Variables & Mean & Median & Mean & Median & & \\
\hline ESG_SCORE $E_{t-1}$ & 0.286 & 0.000 & 0.359 & 0.000 & 0.030 & 0.013 \\
\hline$R O A_{t}$ & 0.008 & 0.007 & 0.004 & 0.005 & 0.000 & 0.004 \\
\hline$S I Z E_{t-1}$ & 20.534 & 20.349 & 20.635 & 20.444 & 0.216 & 0.170 \\
\hline$L E V_{t-1}$ & 1.554 & 0.945 & 1.630 & 0.986 & 0.826 & 0.199 \\
\hline$R O A_{t-1}$ & 0.009 & 0.007 & 0.007 & 0.006 & 0.019 & 0.048 \\
\hline$G R W_{t-1}$ & 0.127 & 0.034 & 0.078 & 0.018 & 0.427 & 0.049 \\
\hline$M B_{t-1}$ & 1.546 & 0.896 & 1.242 & 0.784 & 0.183 & 0.001 \\
\hline Foreignt-1 & 0.117 & 0.067 & 0.115 & 0.067 & 0.730 & 0.802 \\
\hline$O W N_{t-1}$ & 0.435 & 0.436 & 0.435 & 0.449 & 0.953 & 0.864 \\
\hline$A G E_{t}$ & 3.641 & 3.829 & 3.629 & 3.850 & 0.714 & 0.594 \\
\hline $\mathrm{CASHR}_{t-1}$ & 0.084 & 0.064 & 0.087 & 0.060 & 0.501 & 0.681 \\
\hline LOSS $_{t}$ & 0.245 & 0.000 & 0.323 & 0.000 & 0.001 & 0.001 \\
\hline \multicolumn{7}{|c|}{ Panel C: Difference Tests of Variables of ESG and nonESG Firms } \\
\hline & \multicolumn{2}{|c|}{$\begin{array}{c}\text { ESG_FIRM }=0 \\
(n=1265)\end{array}$} & \multicolumn{2}{|c|}{$\begin{array}{c}\text { ESG_FIRM }=1 \\
(n=380)\end{array}$} & \multirow{2}{*}{$\begin{array}{c}t \text {-Tests } \\
(p \text {-Value) }\end{array}$} & \multirow{2}{*}{$\begin{array}{c}\text { Wilcoxon } \\
\text { Tests } \\
\text { ( } p \text {-Value) }\end{array}$} \\
\hline Variables & Mean & Median & Mean & Median & & \\
\hline$E S G \_S C O R E_{t-1}$ & 0.000 & 0.000 & 1.347 & 1.000 & 0.000 & $<0.0001$ \\
\hline$R O A_{t}$ & 0.005 & 0.006 & 0.009 & 0.008 & 0.000 & 0.001 \\
\hline$S I Z E_{t-1}$ & 20.089 & 20.028 & 22.169 & 22.120 & 0.000 & $<0.0001$ \\
\hline$L E V_{t-1}$ & 1.614 & 0.880 & 1.466 & 1.118 & 0.522 & $<0.0001$ \\
\hline$R O A_{t-1}$ & 0.008 & 0.006 & 0.011 & 0.009 & 0.008 & $<0.0001$ \\
\hline$G R W_{t-1}$ & 0.128 & 0.028 & 0.050 & 0.029 & 0.123 & 0.658 \\
\hline$M B_{t-1}$ & 1.474 & 0.842 & 1.331 & 0.897 & 0.474 & 0.020 \\
\hline Foreign $_{t-1}$ & 0.090 & 0.046 & 0.203 & 0.168 & 0.000 & $<0.0001$ \\
\hline$O W N_{t-1}$ & 0.445 & 0.461 & 0.400 & 0.388 & 0.000 & $<0.0001$ \\
\hline$A G E_{t}$ & 3.664 & 3.850 & 3.549 & 3.784 & 0.003 & 0.008 \\
\hline $\mathrm{CASHR}_{t-1}$ & 0.088 & 0.063 & 0.075 & 0.061 & 0.001 & 0.432 \\
\hline$L_{O S S}$ & 0.285 & 0.000 & 0.229 & 0.000 & 0.027 & 0.033 \\
\hline
\end{tabular}

Notes: This table presents the descriptive statistics of the variables used in the empirical analyses. The sample comprises 1645 firm-quarter observations from 2018 to 2020. Panel A presents the descriptive statistics of the sample; Panel B presents the descriptive statistics of the COVID-19 pandemic period $(N=566)$ and before the COVID-19 pandemic $(N=1079)$, and Panel C presents the descriptive statistics of ESG firms $(N=380)$ and nonESG firms $(N=1265)$, separately. A firm is classified as an ESG firm if it has a higher than B+ or B+ grade of ESG total ratings (ESG_SCORE); otherwise, it is a nonESG firm. See Appendix A for the definitions of the variables. 
Table 3. Correlations.

\begin{tabular}{|c|c|c|c|c|c|c|c|c|c|c|c|c|c|}
\hline & (1) & (2) & (3) & (4) & (5) & (6) & (7) & (8) & (9) & (10) & (11) & (12) & (13) \\
\hline (1) $E S G \_S C O R E_{t-1}$ & 1.000 & & & & & & & & & & & & \\
\hline \multirow[t]{2}{*}{ (2) $\mathrm{COVID} t$} & 0.222 & 1.000 & & & & & & & & & & & \\
\hline & 0.395 & & & & & & & & & & & & \\
\hline \multirow[t]{2}{*}{ (3) $R O A_{t}$} & 0.060 & -0.094 & 1.000 & & & & & & & & & & \\
\hline & 0.015 & 0.000 & & & & & & & & & & & \\
\hline \multirow[t]{2}{*}{ (4) $S I Z E_{t-1}$} & 0.577 & 0.030 & 0.113 & 1.000 & & & & & & & & & \\
\hline & $<0.0001$ & 0.223 & $<0.0001$ & & & & & & & & & & \\
\hline \multirow{2}{*}{ (5) $L E V_{t-1}$} & -0.013 & 0.005 & -0.017 & 0.061 & 1.000 & & & & & & & & \\
\hline & 0.598 & 0.834 & 0.487 & 0.013 & & & & & & & & & \\
\hline \multirow[t]{2}{*}{ (6) $R O A_{t-1}$} & 0.044 & -0.051 & 0.339 & 0.115 & -0.017 & 1.000 & & & & & & & \\
\hline & 0.076 & 0.039 & $<0.0001$ & $<0.0001$ & 0.503 & & & & & & & & \\
\hline \multirow[t]{2}{*}{ (7) $G R W_{t-1}$} & -0.019 & -0.015 & 0.018 & 0.025 & -0.021 & 0.037 & 1.000 & & & & & & \\
\hline & 0.439 & 0.537 & 0.455 & 0.311 & 0.391 & 0.139 & & & & & & & \\
\hline \multirow[t]{2}{*}{ (8) $M B_{t-1}$} & -0.014 & -0.024 & 0.027 & -0.020 & 0.819 & 0.017 & -0.019 & 1.000 & & & & & \\
\hline & 0.561 & 0.329 & 0.268 & 0.426 & $<0.0001$ & 0.482 & 0.435 & & & & & & \\
\hline \multirow[t]{2}{*}{ (9) Foreign $n_{t-1}$} & 0.376 & -0.009 & 0.173 & 0.521 & -0.024 & 0.152 & 0.010 & 0.037 & 1.000 & & & & \\
\hline & $<0.0001$ & 0.731 & $<0.0001$ & $<0.0001$ & 0.327 & $<0.0001$ & 0.672 & 0.136 & & & & & \\
\hline \multirow[t]{2}{*}{ (10) $O W N_{t-1}$} & -0.110 & 0.002 & 0.050 & 0.028 & 0.009 & 0.065 & 0.035 & -0.018 & -0.192 & 1.000 & & & \\
\hline & $<0.0001$ & 0.933 & 0.043 & 0.250 & 0.729 & 0.009 & 0.155 & 0.469 & $<0.0001$ & & & & \\
\hline \multirow[t]{2}{*}{ (11) $A G E_{t}$} & -0.095 & -0.010 & -0.024 & -0.016 & 0.020 & -0.064 & 0.026 & -0.011 & -0.077 & -0.039 & 1.000 & & \\
\hline & 0.000 & 0.686 & 0.334 & 0.505 & 0.422 & 0.009 & 0.302 & 0.654 & 0.002 & 0.114 & & & \\
\hline \multirow[t]{2}{*}{ (12) $C A S H R_{t-1}$} & -0.064 & 0.019 & 0.012 & -0.111 & -0.047 & 0.057 & 0.018 & 0.026 & 0.094 & -0.151 & -0.091 & 1.000 & \\
\hline & 0.010 & 0.443 & 0.618 & $<0.0001$ & 0.055 & 0.021 & 0.469 & 0.289 & 0.000 & $<0.0001$ & 0.000 & & \\
\hline \multirow[t]{2}{*}{ (13) LOSS $_{t}$} & -0.054 & 0.083 & -0.609 & -0.159 & 0.017 & -0.264 & -0.025 & -0.014 & -0.189 & -0.124 & 0.022 & 0.036 & 1.000 \\
\hline & 0.029 & 0.001 & $<0.0001$ & $<0.0001$ & 0.491 & $<0.0001$ & 0.319 & 0.579 & $<0.0001$ & $<0.0001$ & 0.381 & 0.140 & \\
\hline
\end{tabular}

Notes: This table shows the Pearson correlation coefficients and $p$-values of the variables used in the empirical analyses. See Appendix A for the definitions of the variables.

\section{Empirical Results and Robustness Checks}

\subsection{Main Results}

Table 4 reports the results of estimating Equation (1) to examine the relationship between firms' ESG and financial performances during the COVID-19 pandemic. We report the results of using the variables of ESG performance as continuous variables (ESG_SCORE) in column (1) and as dummy variables (ESG_FIRM) in column (2). In column (1), the coefficient of ESG, which represents the relationship between $R O A$ and ESG when the value of COVID is zero, is statistically insignificant. These results imply that ESG performance does not have a direct short-term impact on firms' financial performance. However, the coefficient of COVID, which represents the COVID-19 pandemic period, is significantly negative $(-0.003 ; t=-2.66)$. Thus, these results show that the financial performance of most firms has deteriorated due to the COVID-19 pandemic. More importantly, the coefficient of the interaction between ESG and COVID is positive and significant $(0.002 ; t=2.26)$, suggesting that the ESG performance of firms plays a positive role in improving their financial performance during the COVID-19 pandemic. When using the dummy variable $\left(E S G \_F I R M\right)$ as ESG performance, the coefficient of $E S G \times C O V I D$ remains significantly positive in column (2).

The results reported in Table 4 suggest that firms that actively engage in ESG activities are less likely to experience unexpected financial difficulties during the business crisis caused by the COVID-19 pandemic. Furthermore, it suggests that ESG activities can be used as a downside risk management tool for firms.

\subsection{Analyses Based on Individual Categories of ESG Ratings}

We re-estimated our model after replacing the ESG performance measures from the overall ESG score with individual ESG categories. We decomposed the ESG scores into individual KCGS rating categories, i.e., environmental responsibility (Escore), social responsibility (Sscore), and governance (Gscore), because aggregating the various categories of ESG can offset the effect between the individual categories of ESG. For example, Ildong pharmaceutical received a $\mathrm{B}+$ grade for the integrated grade in 2019 but received a grade $\mathrm{A}$ for governance and social responsibility categories and a $\mathrm{C}$ grade or lower for environmental responsibility. Therefore, we analyzed whether individual categories of ESG ratings had a differential impact on a firms' financial performance and the categories that had a greater 
impact on the relationship between ESG and ROA during a business crisis. Table 5 reports the results.

We find that good performance in social responsibility (Sscore) and governance (Gscore) is significantly associated with improved financial performance, as reported in columns (2) and (3), respectively. However, environmental responsibility (Escore) is statistically insignificant. The results suggest that the positive relationship between ESG performance of previous periods and the financial performance of firms during the COVID-19 pandemic is driven by the combined effects of the factor related to social capital formation rather than by only a particular ESG dimension. Therefore, these results imply that firms with good ESG performance pursued shared growth with stakeholders and transparent management and, based on the high trust and ties of stakeholders formed through this, they can conduct business in a relatively stable manner, even during a business crisis. However, efforts related to environmental activities do not seem to have a direct impact on financial performance because it is difficult to achieve tangible results with only a firm's efforts.

Table 4. The effect of ESG performance on firms' financial performance during the COVID-19 pandemic.

\begin{tabular}{|c|c|c|}
\hline \multirow[b]{2}{*}{$E S G=$} & \multicolumn{2}{|c|}{ Dependent Variable: $R O A_{i, t}$} \\
\hline & ESG_SCORE & $E S G=E S G \_F I R M$ \\
\hline Intercept & $0.020 * *$ & $0.021 * *$ \\
\hline ( $t$-value) & $(2.39)$ & $(2.52)$ \\
\hline \multirow[t]{2}{*}{$E S G_{t-1}$} & 0.000 & 0.000 \\
\hline & $(0.03)$ & $(0.44)$ \\
\hline \multirow[t]{2}{*}{ COVID $t$} & $-0.003^{* * *}$ & $-0.003^{* * *}$ \\
\hline & $(-2.66)$ & $(-2.65)$ \\
\hline \multirow{2}{*}{$E S G_{t-1} \times C O V I D_{t}$} & $0.002 * *$ & $0.004^{* *}$ \\
\hline & $(2.26)$ & $(2.51)$ \\
\hline \multirow[t]{2}{*}{$S I Z E_{t-1}$} & 0.000 & 0.000 \\
\hline & $(-0.61)$ & $(-0.78)$ \\
\hline \multirow[t]{2}{*}{$L E V_{t-1}$} & 0.000 & 0.000 \\
\hline & $(-0.47)$ & $(-0.47)$ \\
\hline \multirow{2}{*}{$R O A_{t-1}$} & $0.140 * *$ & $0.139 * *$ \\
\hline & $(2.60)$ & $(2.60)$ \\
\hline \multirow[t]{2}{*}{$G R W_{t-1}$} & 0.000 & 0.000 \\
\hline & $(-1.01)$ & $(-0.94)$ \\
\hline \multirow[t]{2}{*}{$M B_{t-1}$} & 0.000 & 0.000 \\
\hline & $(0.47)$ & $(0.47)$ \\
\hline \multirow[t]{2}{*}{ Foreign $_{t-1}$} & 0.005 & 0.005 \\
\hline & $(1.17)$ & $(1.17)$ \\
\hline \multirow[t]{2}{*}{$O W N_{t-1}$} & -0.002 & -0.002 \\
\hline & $(-0.66)$ & $(-0.56)$ \\
\hline \multirow[t]{2}{*}{$A G E_{t}$} & 0.001 & 0.001 \\
\hline & $(0.79)$ & $(0.82)$ \\
\hline \multirow[t]{2}{*}{$\mathrm{CASHR}_{t-1}$} & 0.002 & 0.002 \\
\hline & $(0.34)$ & $(0.33)$ \\
\hline \multirow[t]{2}{*}{$\operatorname{LOSS}_{t}$} & $-0.024^{* * *}$ & $-0.024^{* * *}$ \\
\hline & $(-18.51)$ & $(-18.50)$ \\
\hline Industry Fixed effect & Yes & Yes \\
\hline $\mathrm{N}$ & 1645 & 1645 \\
\hline Adj $R^{2}$ & 0.434 & 0.435 \\
\hline
\end{tabular}

Notes: this table reports the results of estimating Equation (1): $\mathrm{ROA}_{\text {it }}=\alpha_{0}+\alpha_{1} \mathrm{ESG}_{\text {it } 11}+\alpha_{2} \mathrm{COVID}_{2}+\alpha_{3} \mathrm{ESG}_{\text {it } \_1} \times$ COVID $+\alpha_{4}$ SIZE $_{i t \_1}+\alpha_{5}$ LEV $_{\text {it } \_1}+\alpha_{6}$ ROA $_{i t \_1}+\alpha_{7} \mathrm{GRW}_{\text {it } \_1}+\alpha_{8} \mathrm{MB}_{\mathrm{it} \_1}+\alpha_{9}$ Foreign $_{\text {it } \_1}+\alpha_{10} \mathrm{OWN}_{\text {it } \_1}+\alpha_{11} \mathrm{AGE}_{\mathrm{it}}$ $+\alpha_{12}$ CASHR $_{\text {it } \_1}+\alpha_{13}$ LOSS $_{\text {it }}+\sum$ IND $+\varepsilon_{\text {it. }}$. See Appendix A for the definitions of the variable. All $t$-statistics (in parentheses) are based on the standard errors clustered by firm. ${ }^{* *}$, and ${ }^{* * *}$ denote significance at the $5 \%$, and $1 \%$ levels, respectively, in two-tailed tests. 
Table 5. The effect of ESG performance on firms' financial performance during the COVID-19 pandemic: individual ESG categories.

\begin{tabular}{|c|c|c|c|}
\hline \multirow[b]{2}{*}{$\mathrm{ESG}=$} & \multicolumn{3}{|c|}{ Dependent Variable: $R O A_{i, t}$} \\
\hline & (1) Escore & (2) Sscore & (3) Gscore \\
\hline Intercept & $0.018^{* *}$ & $0.020^{* *}$ & $0.017^{* *}$ \\
\hline ( $t$-value $)$ & $(2.04)$ & $(2.37)$ & $(2.29)$ \\
\hline \multirow[t]{2}{*}{$E S G_{t-1}$} & 0.000 & 0.000 & 0.000 \\
\hline & $(-0.29)$ & $(0.25)$ & $(-0.50)$ \\
\hline \multirow[t]{2}{*}{$\operatorname{COVID}_{t}$} & $-0.002 * *$ & $-0.003^{* *}$ & $-0.006^{*}$ \\
\hline & $(-2.32)$ & $(-2.33)$ & $(-1.93)$ \\
\hline \multirow[t]{2}{*}{$E S G_{t-1} \times C O V I D_{t}$} & 0.001 & $0.001 *$ & $0.001 *$ \\
\hline & $(1.48)$ & $(1.65)$ & $(1.66)$ \\
\hline \multirow{2}{*}{$S I Z E_{t-1}$} & 0.000 & 0.000 & 0.000 \\
\hline & $(-0.21)$ & $(-0.59)$ & $(-0.42)$ \\
\hline \multirow[t]{2}{*}{$L E V_{t-1}$} & 0.000 & 0.000 & 0.000 \\
\hline & $(-0.65)$ & $(-0.57)$ & $(-0.01)$ \\
\hline \multirow[t]{2}{*}{$R O A_{t-1}$} & 0.140 ** & $0.140^{* *}$ & $0.210^{* * *}$ \\
\hline & $(2.60)$ & $(2.60)$ & $(4.23)$ \\
\hline \multirow[t]{2}{*}{$G R W_{t-1}$} & 0.000 & 0.000 & 0.000 \\
\hline & $(-1.01)$ & $(-0.95)$ & $(-1.60)$ \\
\hline \multirow[t]{2}{*}{$M B_{t-1}$} & 0.000 & 0.000 & 0.000 \\
\hline & $(0.60)$ & $(0.55)$ & $(0.08)$ \\
\hline \multirow[t]{2}{*}{ Foreign $_{t-1}$} & 0.005 & 0.005 & 0.004 \\
\hline & $(1.18)$ & $(1.18)$ & $(0.95)$ \\
\hline \multirow[t]{2}{*}{$O W N_{t-1}$} & -0.002 & -0.002 & -0.003 \\
\hline & $(-0.68)$ & $(-0.70)$ & $(-0.92)$ \\
\hline \multirow[t]{2}{*}{$A G E_{t}$} & 0.000 & 0.000 & 0.001 \\
\hline & $(0.65)$ & $(0.70)$ & $(0.76)$ \\
\hline \multirow[t]{2}{*}{$\mathrm{CASHR}_{t-1}$} & 0.002 & 0.003 & 0.004 \\
\hline & $(0.32)$ & $(0.36)$ & $(0.53)$ \\
\hline \multirow{2}{*}{$\operatorname{LOSS}_{t}$} & $-0.023^{* * *}$ & $-0.024^{* * *}$ & $-0.023^{* * *}$ \\
\hline & $(-18.49)$ & $(-18.41)$ & $(-17.83)$ \\
\hline Industry Fixed effect & Yes & Yes & Yes \\
\hline $\mathrm{N}$ & 1645 & 1645 & 1645 \\
\hline Adj $R^{2}$ & 0.433 & 0.434 & 0.444 \\
\hline $\begin{array}{l}\text { Notes: this table reports th } \\
\text { COVID }+\alpha_{4} \text { SIZE }_{\text {it_1 } 1}+\alpha_{5} \\
\alpha_{12} \text { CASHR } \\
\text { it_ } 11+\alpha_{13} \text { LOS }\end{array}$ & timating & $\begin{array}{l}\mathrm{A}_{\text {it }}=\alpha_{0}+ \\
\mathrm{BB}_{\text {it_1 } 1}+\alpha_{9} \mathrm{~F} \\
\text { he definitio } \\
*, * * \text {, and } * *\end{array}$ & $\begin{array}{l}\text { OVID }+\alpha_{3} E \\
\mathrm{OWN}_{\text {it_1 }}+\alpha \\
\text { les. All t-stat }\end{array}$ \\
\hline
\end{tabular}

\subsection{Additional Tests}

\subsubsection{Earnings Volatility}

We also analyzed the impact of ESG performance on firms' financial performance during the COVID-19 pandemic using earnings volatility as a variable. If a firm's financial performance has not changed significantly during the business crisis period, it implies that the firm's management has been stable. Therefore, we employ earnings volatility as an alternative financial performance measure to examine whether firms with good ESG performance have achieved more stable business performance than firms with poor ESG performance. We measure earnings volatility as the standard deviation of the net income in the past five years. Table 6 presents the results. We find that the coefficient of COVID is significantly positive in all columns, suggesting that the earnings volatility of most firms is higher during the COVID-19 pandemic. However, we also find that the coefficient of $E S G \times C O V I D$ is significantly negative except for Escore. These results are consistent with our main findings. 
Table 6. The effect of ESG performance on earnings volatility during the COVID-19 pandemic: an alternative measure of earnings performance.

\begin{tabular}{|c|c|c|c|c|c|}
\hline \multirow{3}{*}{$E S G=$} & \multicolumn{5}{|c|}{ Dependent Variable: $R O A V O L_{i, t}$} \\
\hline & (1) & (2) & (3) & (4) & (5) \\
\hline & $E S G \_S C O R E$ & $E S G \_F I R M$ & Esocore & Sscore & Gscore \\
\hline \multirow{4}{*}{$\begin{array}{c}\text { Intercept } \\
\text { (t-value) } \\
E S G_{t-1}\end{array}$} & 0.001 & 0.003 & 0.003 & 0.004 & 0.007 \\
\hline & $(0.14)$ & $(0.40)$ & $(0.32)$ & $(0.44)$ & (1.34) \\
\hline & 0.000 & -0.001 & 0.000 & 0.000 & $-0.001^{* *}$ \\
\hline & $(-0.75)$ & $(-0.68)$ & $(-0.40)$ & $(0.29)$ & $(-2.23)$ \\
\hline \multirow{2}{*}{$\operatorname{COVID}_{t}$} & $0.006^{* * *}$ & $0.005^{* * *}$ & $0.005^{* * *}$ & $0.006^{* * *}$ & $0.006^{* * *}$ \\
\hline & (7.55) & (11.73) & (9.02) & (6.28) & $(5.60)$ \\
\hline \multirow{2}{*}{$\begin{array}{c}E S G_{t-1} \times \\
\operatorname{COVID}_{t}\end{array}$} & $-0.001^{* *}$ & $-0.002^{* *}$ & -0.001 & $-0.001^{*}$ & $-0.001 *$ \\
\hline & $(-2.16)$ & $(-2.53)$ & $(-1.33)$ & $(-1.89)$ & $(-1.89)$ \\
\hline \multirow[t]{2}{*}{$S I Z E_{t-1}$} & 0.000 & 0.000 & 0.000 & 0.000 & 0.000 \\
\hline & $(-0.02)$ & $(-0.35)$ & $(-0.29)$ & $(-0.48)$ & $(-0.95)$ \\
\hline \multirow[t]{2}{*}{$L E V_{t-1}$} & 0.000 & 0.000 * & 0.000 * & 0.000 & 0.000 \\
\hline & (1.53) & $(1.69)$ & $(1.82)$ & (1.86) & (1.04) \\
\hline \multirow[t]{2}{*}{$R O A_{t-1}$} & 0.058 & 0.058 & 0.057 & 0.058 & 0.110 * \\
\hline & (1.03) & $(1.04)$ & (1.01) & (1.03) & $(1.82)$ \\
\hline \multirow[t]{2}{*}{$G R W_{t-1}$} & $0.000 * * *$ & $0.000 * * *$ & $0.000 * * *$ & $0.000 * * *$ & 0.000 * \\
\hline & $(2.90)$ & $(2.76)$ & (2.90) & (2.89) & $(1.75)$ \\
\hline \multirow[t]{2}{*}{$M B_{t-1}$} & 0.000 & 0.000 & 0.000 & 0.000 & 0.000 \\
\hline & $(-0.15)$ & $(-0.25)$ & $(-0.29)$ & $(-0.31)$ & $(0.06)$ \\
\hline \multirow[t]{2}{*}{ Foreign $_{t-1}$} & -0.003 & -0.004 & -0.003 & -0.004 & -0.004 * \\
\hline & $(-1.31)$ & $(-1.35)$ & $(-1.02)$ & $(-1.37)$ & $(-1.71)$ \\
\hline \multirow[t]{2}{*}{$O W N_{t-1}$} & 0.004 & 0.004 & 0.004 & 0.004 & -0.001 \\
\hline & $(0.49)$ & $(0.49)$ & $(0.50)$ & (0.53) & $(-0.28)$ \\
\hline \multirow[t]{2}{*}{$A G E_{t}$} & -0.001 & -0.001 & -0.001 & -0.001 & 0.000 \\
\hline & $(-1.01)$ & $(-0.99)$ & $(-0.92)$ & $(-0.91)$ & $(-0.84)$ \\
\hline \multirow{2}{*}{$\mathrm{CASHR}_{t-1}$} & 0.011 & 0.011 & 0.011 & 0.011 & $0.016^{* *}$ \\
\hline & (1.58) & (1.61) & (1.57) & (1.58) & $(2.58)$ \\
\hline \multirow[t]{2}{*}{$\operatorname{LOSS}_{t}$} & $0.004^{* * *}$ & $0.004^{* * *}$ & $0.004^{* *}$ & $0.004^{* *}$ & $0.003^{* * *}$ \\
\hline & $(2.62)$ & (2.63) & $(2.60)$ & $(2.57)$ & (3.48) \\
\hline $\begin{array}{c}\text { Industry Fixed } \\
\text { effect }\end{array}$ & Yes & Yes & Yes & Yes & Yes \\
\hline $\mathrm{N}$ & 1645 & 1645 & 1645 & 1645 & 1645 \\
\hline $\operatorname{Adj} R^{2}$ & 0.078 & 0.077 & 0.078 & 0.078 & 0.142 \\
\hline
\end{tabular}

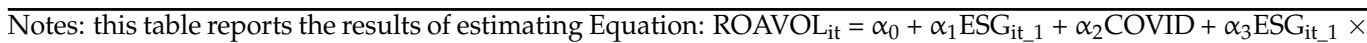
COVID $+\alpha_{4} \mathrm{SIZE}_{\mathrm{it} \_1}+\alpha_{5} \mathrm{LEV}_{\mathrm{it} \_1}+\alpha_{6} \mathrm{ROA}_{\mathrm{it} \_1}+\alpha_{7} \mathrm{GRW}_{\mathrm{it} \_1}+\alpha_{8} \mathrm{MB}_{\mathrm{it} \_1}+\alpha_{9}$ Foreign $_{\text {it_1 } 1}+\alpha_{10} \mathrm{OWN}_{\mathrm{it} \_1}+\alpha_{11} \mathrm{AGE}_{\mathrm{it}}$ $+\alpha_{12}$ CASHR $_{i t \_1}+\alpha_{13}$ LOSS $_{i t}+\sum \mathrm{IND}+\varepsilon_{\mathrm{it}}$. See Appendix A for the definitions of the variables. All t-statistics (in parentheses) are based on the standard errors clustered by firm. *,**, and *** denote significance at the $10 \%, 5 \%$, and $1 \%$ levels, respectively, in two-tailed tests.

\subsubsection{Endogeneity Problem}

The differences in the characteristics of ESG and nonESG firms may affect our results. In a pandemic environment, these results could be driven by innately different firms enacting ESG and performing well. For instance, firm size is correlated with ESG performance [19,39], and public visibility affects CSR engagement [40]. To mitigate this concern, following Yeo et al., (2015) and Rhee et al., (2021) [31,41], we used a propensity score matching (PSM) technique. We first ran a logistic regression model that estimated the probability of being classified as an ESG firm (ESG_FIRM) using several firm characteristic variables. These included leverage ( $L E V)$, firm size (SIZE), firm performance $(R O A)$, financial resources (CASHR), negative net income (LOSS), foreign ownership (OWN), firm age $(A G E)$, and industry and year fixed effects. We then matched each ESG firm with a control firm (i.e., a nonESG firm) with the closest propensity score, without replacement within a maximum caliper distance of $1 \%$ of the standard deviation of $p$-scores. We successfully matched 216 ESG firms with 216 nonESG firms, resulting in a matched sample of 432 observations. As presented in Panel A, the mean and median values of all covariates between the treatment and control samples are not significantly different.

Panel B of Table 7 presents the results of estimating Equation (1) for the matched sample. The results are largely consistent with those reported in Table 4. Specifically, the coefficient of ESG_FIRM $\times$ COVID is positive and significant $(0.005, t=2.44)$. The PSM 
results suggest that our main inferences are unlikely to be influenced by differences in the characteristics between ESG and nonESG firms.

Table 7. The effect of ESG performance on firms' financial performance during the COVID-19 pandemic: propensity score matching.

\begin{tabular}{|c|c|c|c|c|c|c|}
\hline \multicolumn{7}{|c|}{ Panel A: Difference Tests of ESG and nonESG Firms Variables } \\
\hline \multirow[b]{2}{*}{ Variables } & \multicolumn{2}{|c|}{$\begin{array}{c}E S G_{-} F I R M=0 \\
(n=216)\end{array}$} & \multicolumn{2}{|c|}{$\begin{array}{c}E S G \_F I R M=1 \\
(n=216)\end{array}$} & \multirow{2}{*}{$\begin{array}{c}t \text {-Tests } \\
(p \text {-Value })\end{array}$} & \multirow{2}{*}{$\begin{array}{c}\text { Wilcoxon } \\
\text { Tests } \\
\text { (p-Value) }\end{array}$} \\
\hline & Mean & Median & Mean & Median & & \\
\hline$L E V_{t}$ & 1.512 & 1.110 & 1.578 & 1.148 & 0.910 & 0.942 \\
\hline$S I Z E_{t}$ & 21.343 & 21.347 & 21.387 & 21.338 & 0.608 & 0.635 \\
\hline$R O A_{t}$ & 0.008 & 0.008 & 0.007 & 0.006 & 0.500 & 0.464 \\
\hline $\mathrm{CASHR}_{t}$ & 0.082 & 0.067 & 0.080 & 0.062 & 0.648 & 0.927 \\
\hline LOSS $_{t}$ & 0.378 & 0.000 & 0.402 & 0.000 & 0.942 & 0.942 \\
\hline Foreign $_{t}$ & 0.124 & 0.089 & 0.130 & 0.100 & 0.567 & 0.105 \\
\hline$A G E_{t}$ & 3.487 & 3.829 & 3.505 & 3.761 & 0.792 & 0.680 \\
\hline
\end{tabular}

Panel B: Results Based on the Matched Sample

\begin{tabular}{|c|c|}
\hline Variables & Dependent Variable: $R O A_{i, t}$ \\
\hline $\begin{array}{l}\text { Intercept } \\
(t \text {-value })\end{array}$ & $\begin{array}{l}0.043^{* *} \\
(2.96)\end{array}$ \\
\hline$E S G \_F I R M_{t-1}$ & $\begin{array}{l}-0.002 \\
(-1.25)\end{array}$ \\
\hline COVID $_{t}$ & $\begin{array}{l}-0.004^{*} * \\
(-2.41)\end{array}$ \\
\hline$E S G_{-}$FIRM $_{t-1} \times \operatorname{COVID}_{t}$ & $\begin{array}{l}0.005^{* *} \\
(2.44)\end{array}$ \\
\hline$S I Z E_{t-1}$ & $\begin{array}{l}-0.001 \\
(-1.26)\end{array}$ \\
\hline$L E V_{t-1}$ & $\begin{array}{l}0.000 \\
(-0.54)\end{array}$ \\
\hline$R O A_{t-1}$ & $\begin{array}{l}0.091 \\
(1.00)\end{array}$ \\
\hline$G R W_{t-1}$ & $\begin{array}{l}-0.000 \\
(-1.28)\end{array}$ \\
\hline$M B_{t-1}$ & $\begin{array}{l}0.000 \\
(0.59)\end{array}$ \\
\hline Foreign $_{t-1}$ & $\begin{array}{l}0.010 \\
(1.53)\end{array}$ \\
\hline$O W N_{t-1}$ & $\begin{array}{l}-0.008 * \\
(-1.83)\end{array}$ \\
\hline$A G E_{t}$ & $\begin{array}{c}0.000 \\
(-0.14)\end{array}$ \\
\hline $\mathrm{CASHR}_{t-1}$ & $\begin{array}{l}-0.012 \\
(-1.41)\end{array}$ \\
\hline$L_{O S S}$ & $\begin{array}{l}-0.019 * * * \\
(-13.75)\end{array}$ \\
\hline Industry Fixed effect & Yes \\
\hline $\mathrm{N}$ & 432 \\
\hline $\operatorname{Adj} R^{2}$ & 0.551 \\
\hline
\end{tabular}

Notes: Panel A of this table presents the difference tests of ESG and nonESG firms variables based on the matched sample. The sample consists of 432 firm-quarter observations with 216 corresponding matched pairs. Panel B presents the regression results based on the matched sample. All $\mathrm{t}$-statistics (in parentheses) are based on the standard errors clustered by firm. $* * *$, and ${ }^{* *}$ denote significance at the $10 \%, 5 \%$, and $1 \%$ levels, respectively, in two-tailed tests. 


\section{Conclusions}

This study empirically examined the relationship between ESG management performance and financial performance during the business crisis caused by the COVID-19 pandemic.

The results show that the performance of ESG activities is to protect firms from a sharp decline in financial performance due to the COVID-19 pandemic. ROA of firms listed in the Korean capital market fell sharply due to the sudden shock of the COVID-19 pandemic in the first quarter of 2020. However, the extent of the decline is smaller for firms with a higher performance of ESG activities, especially in two subdimensions of ESG-social responsibility (S) and governance (G). We also find that the performance of ESG activities not only has a significant effect on increasing profitability but also on decreasing earnings volatility during the COVID-19 pandemic.

This study is meaningful in that it empirically investigates how ESG activities affect corporate financial performance during the business crisis caused by the COVID-19 pandemic. However, in recent times, there have been increasing interests in ESG activities and intensified discussions on ESG management performance; that said, findings about whether ESG activities lead to financial performance are inconsistent. This paper's findings suggest that ESG activities are not just expenditures that undermine shareholders' wealth but that they can mutually benefit corporate stakeholders during a crisis.

This study also provides implications for users of accounting information and regulators. In an environment of increasing uncertainty, a firm's ESG activities will become an important metric for market participants' decision making. Accounting information users can expect that fluctuations in market uncertainty will not have a high impact on financial performance in firms with high ESG performance. Therefore, a firm's ESG performance should be used in their various decision-making processes. In addition, regulators need to make efforts to encourage ESG activities in firms to increase market stability. Many countries made use of ultra-short-term financial support schemes to bolster economies stagnated by COVID-19. Along with these efforts, in order to minimize the impact of uncertainty, it is necessary to improve the overall business environment of firms in the long term. As part of efforts to improve the business environment, regulators need to encourage corporate ESG activities and manage the performance of ESG activities, such as mandatory disclosure of ESG performance.

We acknowledge the potential limitations of our study, which are related to measurement errors. The generalizability of the findings in this study may be limited as they are based on the data for the first quarter of 2020; additional research in other business crisis environments is required to provide more generalizable findings on whether ESG activities play a positive role in improving financial performance. In addition, there is another limitation related to generalization in that this study only targeted Korean capital markets. Another limitation of this study was that it did not control for other potential factors that could affect ESG engagement and financial outcomes. Based on this study, we expect that various and in-depth studies on the channels that link the relationship between ESG activities and corporate performance will continue.

Author Contributions: Conceptualization, J.H. and H.K.; methodology, J.H. and H.K.; software, J.H.; validation, J.H., H.K. and D.J.; formal analysis, J.H.; investigation, J.H. and D.J.; resources, D.J.; data curation, J.H. and D.J.; writing-original draft preparation, J.H. and H.K.; writing-review and editing, J.H., H.K. and D.J.; supervision, H.K.; project administration, J.H. All authors have read and agreed to the published version of the manuscript.

Funding: This research received no external funding.

Institutional Review Board Statement: Not applicable.

Informed Consent Statement: Not applicable.

Data Availability Statement: Not applicable.

Conflicts of Interest: The authors declare no conflict of interest. 


\section{Appendix A}

Table A1. Variable definitions.

\begin{tabular}{|c|c|}
\hline Variable & Definition \\
\hline$R O A$ & net income divided by total assets at the beginning of the year \\
\hline ROAVOL & standard deviation of ROA measured over years $t$ through $t-4$ \\
\hline ESG_SCORE & $\begin{array}{l}\text { ordinal variable that takes a value of } 3 \text { if a firm receives an A+ or higher ESG total grade provided by KCGS, } \\
2 \text { if a firm receives an A grade, } 1 \text { if a firm receives a B+ grade, and } 0 \text { otherwise }\end{array}$ \\
\hline ESG_FIRM & indicator variable that takes a value of 1 if a firm has a $\mathrm{B}+$ or higher grade, and 0 otherwise \\
\hline Escore & $\begin{array}{l}\text { ordinal variable that takes a value of } 3 \text { if a firm receives an } A+\text { or higher environmental grade provided by } \\
\text { KCGS, } 2 \text { if a firm receives an A grade, } 1 \text { if a firm receives a } B+\text { grade, and } 0 \text { otherwise }\end{array}$ \\
\hline Sscore & $\begin{array}{l}\text { ordinal variable that takes a value of } 3 \text { if a firm receives an } A+\text { or higher social grade provided by KCGS, } 2 \text { if } \\
\text { a firm receives an A grade, } 1 \text { if a firm receives a B+ grade, and } 0 \text { otherwise } \\
\text { ordinal variable that takes a value of } 5 \text { if a firm receives an } A+\text { or higher corporate governance grade }\end{array}$ \\
\hline Gscore & $\begin{array}{l}\text { provided by KCGS, } 4 \text { if a firm receives an } A \text { grade, } 3 \text { if a firm receives a B+ grade, } 2 \text { if a firm receives a B } \\
\text { grade, one if a firm receives a } C \text { grade, and } 0 \text { otherwise }\end{array}$ \\
\hline COVID & indicator variable that is set as 1 if $t$ is 2020 \\
\hline SIZE & natural logarithm of total assets \\
\hline$L E V$ & total debt divided by equity \\
\hline GRW & growth rate of sales \\
\hline$M B$ & the market value of equity divided by the book value of equity \\
\hline Foreign & the proportion of the common stock held by foreign investors \\
\hline OWN & the proportion of the common stock held by the largest shareholder \\
\hline$A G E$ & $\begin{array}{l}\text { firm age, defined as the natural logarithm of } 1 \text { plus the number of years since the firm was listed on the stock } \\
\text { market }\end{array}$ \\
\hline $\begin{array}{l}\text { CASHR } \\
\text { LOSS }\end{array}$ & $\begin{array}{l}\text { cash holdings, defined as cash and marketable securities divided by total assets at the beginning of the year } \\
\text { indicator variable that takes a value of } 1 \text { if a firm's net income is negative and } 0 \text { otherwise }\end{array}$ \\
\hline
\end{tabular}

\section{References}

1. Roubini, N. A Greater Depression; Project Syndicate: Prague, Czech Republic, 2020.

2. Aupperle, K.E.; Carroll, A.B.; Hatfield, J.D. An empirical examination of the relationship between corporate social responsibility and profitability. Acad. Manag. J. 1985, 28, 446-463.

3. Lys, T.; Naughton, J.P.; Wang, C. Signaling through corporate accountability reporting. J. Account. Econ. 2015, 60, 56-72. [CrossRef]

4. Barnea, A.; Rubin, A. Corporate social responsibility as a conflict between shareholders. J. Bus. Ethics 2010, 97, 71-86. [CrossRef]

5. Griffin, J.J.; Mahon, J.F. The corporate social performance and corporate financial performance debate: Twenty-five years of incomparable research. Bus. Soc. 1997, 36, 5-31. [CrossRef]

6. Brammer, S.; Millington, A. Corporate reputation and philanthropy: An empirical analysis. J. Bus. Ethics 2005, 61, 29-44. [CrossRef]

7. Valentine, S.; Fleischman, G. Ethics programs, perceived corporate social responsibility and job satisfaction. J. Bus. Ethics 2008, 77, 159-172. [CrossRef]

8. Dhaliwal, D.; Li, O.; Zhang, A.; Yang, Y. Voluntary nonfinancial disclosure and the cost of equity capital: The initiations of corporate social responsibility reporting. Account. Rev. 2011, 86, 59-100. [CrossRef]

9. Godfrey, P.C. The relationship between corporate philanthropy and shareholder wealth: A risk management perspective. Acad. Manag. Rev. 2005, 30, 777-798. [CrossRef]

10. Lins, K.V.; Servaes, H.; Tamayo, A. Social capital, trust, and firm performance: The value of corporate social responsibility during the financial crisis. J. Financ. 2017, 72, 1785-1824. [CrossRef]

11. De Vito, A.; Gomez, J.P. Estimating the COVID-19 cash crunch: Global evidence and policy. J. Account. Public Policy 2020, 39, 106741. [CrossRef]

12. Demers, E.; Hendrikse, P.J.; Lev, B. ESG did not immunize stocks during the COVID-19 crisis, but investments in intangible assets did. J. Bus. Financ. Account. 2021, 48, 433-462. [CrossRef] [PubMed]

13. Bowen, H.R. Social Responsibilities of the Businessman; Harper and Brothers: New York, NY, USA, 1953.

14. Freeman, R.E. Strategic Management: A Stakeholder Approach; Pittman Publishing Inc.: Marshfield, MA, USA, 1984.

15. Meyer, J.W.; Rowan, B. Institutionalized organizations: Formal structure as myth and ceremony. Am. J. Sociol. 1977, 83, 340-363. [CrossRef]

16. Deegan, C.; Unerman, J. Financial Accounting Theory, 2nd ed.; McGraw Hill Education: Maidenhead, UK, 2011.

17. Prior, D.; Surroca, J.; Tribó, J.A. Are socially responsible managers really ethical? Exploring the relationship between earnings management and corporate social responsibility. Corp. Gov. 2008, 16, 160-177. [CrossRef] 
18. Surroca, J.; Tribó, J.A. Managerial entrenchment and corporate social performance. J. Bus. Financ. Account. 2008, 35, 748-789. [CrossRef]

19. Waddock, S.; Graves, S. The corporate social performance-financial performance link. Strateg. Manag. J. 1997, 18, 303-319. [CrossRef]

20. Roman, R.; Hayibor, S.; Agle, B. The relationship between social performance and financial performance. Bus. Soc. 1999, 38, 109-125. [CrossRef]

21. Luo, X.; Bhattacharya, C.B. Corporate social responsibility, customer satisfaction, and market value. J. Mark. 2006, 70, 1-18. [CrossRef]

22. Surroca, J.; Tribó, J.A.; Waddock, S. Corporate responsibility and financial performance: The role of intangible resources. Strateg. Manag. J. 2010, 31, 463-490. [CrossRef]

23. Aboud, A.; Diab, A. The impact of social, environmental and corporate governance disclosures on firm value: Evidence from Egypt. J. Account. Emerg. Econ. 2018, 8, 442-458. [CrossRef]

24. Edmans, A. Does the stock market fully value intangibles? Employee satisfaction and equity prices. J. Financ. Econ. 2011, 101, 621-640. [CrossRef]

25. Li, Z.; Frank, D.B.M.; Wang, J.; Yu, C. A learning curve of the market: Chasing alpha of socially responsible firms. J. Econ. Dyn. Control 2019, 109, 103772. [CrossRef]

26. Kang, W.; Jung, M. Effect of ESG activities and firm's financial characteristics. Korean J. Financ. Stud. 2020, 49, 681-707. [CrossRef]

27. Hillman, A.J.; Keim, G.D. Shareholder value, stakeholder management, and social issues: What's the bottom line? Strateg. Manag. J. 2001, 22, 125-139. [CrossRef]

28. Brammer, S.; Brooks, C.; Pavelin, S. Corporate social performance and stock returns: UK evidence form disaggregate measures. Financ. Manag. 2006, 35, 97-116. [CrossRef]

29. Duque-Grisales, E.; Aguilera-Caracuel, J. Environmental, social and governance (ESG) scores and financial performance of multilatinas: Moderating effects of geographic international diversification and financial slack. J. Bus. Ethics 2021, 168, 315-334. [CrossRef]

30. Byun, H. Impact of ESG factors on firm value in Korea. J. Int. Trade Commer. 2018, 14, 135-160. [CrossRef]

31. Yeo, Y.J.; Choi, S.J.; Kwon, O.J. CSR activities as a competitive strategy based on industry competition and firm performance: Focusing on the market type. Korean Account. Rev. 2015, 40, 1-37.

32. Shehzad, K.; Sarfraz, M.; Shah, S.G.M. The impact of COVID-19 as a necessary evil on air pollution in India during the lockdown. Environ. Pollut. 2020, 266, 115080. [CrossRef]

33. World Bank. Global Economic Prospects; World Bank: Washington, DC, USA, 2020

34. Hale, J. Sustainable Equity Funds Outperform Traditional Peers in 2020; Morningstar Sustainability Matters: Chicago, IL, USA, 2021.

35. Adler, P.S.; Kwon, S.W. Social capital: Prospects for a new concept. Acad. Manag. Rev. 2002, 27, 17-40. [CrossRef]

36. Coleman, J.S. Foundations of Social Theory; Harvard University Press: Cambridge, MA, USA, 1990.

37. Sacconi, L.; Antoni, G. Social Capital, Corporate Social Responsibility, Economic Behaviour and Performance; Springer: Berlin/Heidelberg, Germany, 2010.

38. Bae, C.; Kim, T.; Shin, S. The trend of studies using non-financial measures in the field of accounting and ESG issue. Korean Account. J. 2021, 30, 235-276. [CrossRef]

39. McWilliams, A.; Siegel, D. Corporate social responsibility and financial performance: Correlation or misspecification? Strateg. Manag. J. 2000, 21, 603-609. [CrossRef]

40. Li, F.; Young, B.; Morris, T. Corporate Visibility in Print Media and Corporate Social Responsibility. Sustainability 2018, 10, 1-18.

41. Rhee, C.S.; Jung, A.; Chun, H. A study on ESG determinants and firm value: Focusing on economic policy uncertainty and operating income volatility. In Proceedings of the 2021 Korean Accounting Association Summer International Conference, Seoul, Korea, 20-22 June 2021. 